\title{
अलिखित उपन्यासमा प्रयोगशील नवीनता
}

\author{
घनश्याम दाहाल, विद्यावारिधि \\ सहप्राध्यापक \\ पिण्डेश्वर विद्यापीठ, धरान
}

DOI: https://doi.org/10.3126/dristikon.v11i1.39167

\begin{abstract}
लेखसार
नेपाली साहित्यका विशिष्ट स्रष्टा र धरोहर उपन्यासकार ध्रुवचन्द्र गौतमको औपन्यासिक जगत्मा उल्लेखनीय योगदान र विशिष्ट पहिचान रहेको छ। उपन्यास साहित्यका क्षेत्रमा उनले गरेको योगदान अनुकरणीय मानिन्छ। उनका औपन्यासिक संरचनाले नेपाली साहित्यको भण्डारलाई वैभवशाली र सम्पन्नशाली बनाएको छ। नेपाली आधुनिक उपन्यासको विकासको यात्रामा प्रयोगवादी धाराको प्रतिनिधित्व गर्दे औपन्यासिक जगत्लाई उचाइमा पुच्याउन उनले गरेको योगदान अविस्मरणीय मानिन्छ। 'अलिखित' वि.सं. २०४० सालमा प्रकाशित भई मदन पुरस्कार प्राप्त गरेको आन्चलिकतालाई मुख्यरूपमा आफ्नो दस्तावेज बनाएको विशिष्ट प्रयोगधर्मी उपन्यास हो । यसमा तराईको भूभाग वीरगज्जको नजिकमा रहेको बिरहिनपुर बरेवा गाउँको जनजीवनको वास्तविक भाँकी प्रस्तुत गरिएको छ। सरकारको दृष्टि नपरेको गाउँको सांस्कृतिक उत्वननको विषय उपन्यासको मुख्य प्रतिपाद्य आधार बनेको छ। विचित्रको गाउँको विचित्र क्रियाकलापको चित्रण यसको महत्त्वपूर्ण पक्ष हो। ग्रामीण जनजीवनका गरिबी, अशिक्षा, पछ्छौटेपन, सामन्ती संस्कार यसका मुख्य प्रतिपाद्य विषय हुन् । बरेवाको जनजीवनको यथार्थ प्रस्तुति नै यसको मुख्य दस्तावेज हो। परम्परागत उपन्यास रचनाको शिल्प सौन्दर्यबाट पूर्ण रूपमा मुक्त भई स्वतन्त्र र नवीन प्रयोग यस उपन्यासको औपन्यासिक प्राप्ति, मान्यता र चिन्तन हो । उपन्यासमा अभिव्यक्त बिरहिनपुरको किंवदन्ती र दोरहन्तल पोखरीको किंवदन्तीले मिथकीय मान्यतालाई आत्मसात गरेको देखिन्छ। अस्वाभाविक, अयथार्थ स्वैरकल्पनालाई सबल र प्रभावकारी बनाएर प्रस्तुत गर्नु यसको उल्लेखनीय चिन्तन देखिन्छ । कथानक, पात्र र संरचनामा नयाँपनको खोजी यसमा सबल रूपमा गरिएको छ। बिरहिनपुर बरेवा गाउँको भौगोलिक, सांस्कृतिक, आर्थिक र भाषिक विशेषताको उजागर गर्दे त्यसको वास्तविकताको सूक्ष्म विश्लेषण नै यसको मुख्य सार हो ।

शब्दकुज्जी : किंवदन्ती, दोरहन्तल, आज्चलिक, स्वैरकल्पना, मिथकीय
\end{abstract}

\section{विषयपरिचय}

नेपाली साहित्यमा बहुमुखी प्रतिभाका धनी व्यक्तित्वका रूपमा ध्रुवचन्द्र गौतमको (२००७)महत्त्वपूर्ण भूमिका र उत्कृष्ट पहिचान रहेको छ। उनका कृतिहरू नेपाली साहित्यको भण्डारमा अमूल्य निधिका रूपमा रहेका छन्। उनले वीरगज्जको त्रिजुद्ध मा.वि.बाट एस.एल.सी. र त्रिचन्द्र कलेजबाट आइ.ए. र बि. ए. तथा त्रि.वि. कीर्तिपुरबाट एम.ए. र भारतको पुणे विश्वविद्यालयबाट विद्यावारिधि उपाधि प्राप्त गरेका थिए। गौतम २०२४ सालदेखि नै सरकारी सेवामा प्रवेश गरी २०४१ सालसम्म त्रिभुवन विश्वविद्यालय कीर्तिपुरमा प्राध्यापन कार्यमा संलग्न भएका थिए । उनको साहित्यिक जीवनको प्रारम्भ २०२० सालमा रूपरेखा पत्रिकमा प्रकाशित 'तटस्थता : असफलता' कविता र 'एक यात्रा अनुभूति शीर्षकको कथाबाट भएको हो । उनले नेपाली उपन्यास साहित्यमा गहकिलो योगदान पुय्याएका छन् । अन्त्यपछि (२०२४), बालुवामाथि (२०२६), डापी (२०३३), कट्टेल सरको चोटपटक (२०३७), 
अलिखित (२०४०), निमित्त नायक (२०४३), स्वर्गीय हिरादेवीको खोज (२०४५), एक सहरमा एक कोठा (२०४६), उपसंहार अर्थात् चौथो अन्त्य (२०४६, दुविधा (२०४२), अगिनदत्त+अग्निदत्त (२०४३), फलको आतड्क (२०४६), बाढी (२०४६), सहस्राब्दीको अन्तिम प्रेमकथा (२०५६), मौन (२०५६) तथा कथित (२०५९), भीमसेन - ४ को खोजी (२०६०), घुर्मी (२०६२), जेलिएको (२०६२) र एक असफल आख्यानको आरम्भ (२०६४) महCEवपूर्ण उपन्यास प्रकाशित छन् ।उनको सहलेखनमा आकाश विभाजित छ (२०३०) उपन्यास पनि प्रकाशित देखिन्छ। उनका औपन्यासिक कृतिहरू नेपाली साहित्यको भण्डारमा अमूल्य सम्पत्तिका रूपमा रहेका छन् ।

साहित्यका विविध क्षेत्रमा कलम चलाउने गौतमले उपन्यास जगत्मा अमूल्य कृति सिर्जना गरेर ठूलो गुन लगाएका छन्। गौतम विसड्गतिवादी उपन्यासकार हुन्। उनका उपन्यासमा विसड्गतिवादी चिन्तन मुखरित भएको देखिन्छ। पात्रका विसड्गत जीवन र निराशावादी सोचहरू उपन्यासमा अभिव्यक्त भएको देखिन्छ। उनले आफ्ना उपन्यासमा विसड्गत जीवनभित्र अस्तित्वको खोजी गरेका छन्। मान्छे अनेक दु:ख, कष्ट, निराशा र विसड्गत अवस्थालाई आत्मसात गर्दे आफ्नो अस्तित्वको खोजीका लागि सड्घर्ष गर्न विवश देखिन्छ। निस्सार जीवनलाई पनि सारपूर्ण बनाउन सड्घर्ष गर्नु अस्तित्वको परिणाम हो। उनका उपन्यासमा आलोचनात्मक यथार्थवादी चिन्तन पाइन्छ। सामाजिक विकृति विसड्गति र अस्तव्यवस्तता प्रति तीव्र आलोचना गर्दे समतामूलक समाजको परिकल्पना गर्नु यसको विशिष्ट पक्ष हो उनका उपन्यासमा प्रयोगवादी चिन्तन पनि सबल रूपमा अभिव्यक्त भएको देखिन्छ। परम्परागत मान्यताभन्दा भिन्न पहिचान उनका उपन्यासमा पाइन्छ। उनको अलिखित प्रयोगवादी उपन्यास हो। यसमा पात्र र कथावस्तु नभएर उत्वनन टोलीको आफ्नो कार्य र परिस्थितिलाई मात्र उजागर गरेर उपन्यासलाई सकिएको छ। मिथक र स्वैरकल्पनालाई सबल रूपमा प्रयोग गरेर उपन्यासलाई भव्य र विशिष्ट बनाउने प्रयत्न भएको छ

काल्पनिक प्रस्तुतिबाट यथार्थको सूक्ष्म निरिक्षण उनको महत्त्वपूर्ण पक्ष हो । एउटा जादुमय संसारको रचना गरेर जीवन भोगाइलाई त्यही संसारभित्र घुलमेल गराउनु उनको स्वैरकल्पनाको विशिष्ट प्रयोग मानिन्छ ाशंकर कोइरालाको खैरेनीघाट उपन्यासले आज्चलिक उपन्यास लेखन परम्परालाई भित्र्याएको र त्यस परम्परालाई अक्षुण्ण योगदान पुच्याउने सन्दर्भमा गौतमको अलिखित उपन्यास आएको छ। यसमा नवीन भाषा र शैलीको योजना सबल रूपमा गरिएको छ।अचेतन मनबाट अनुप्राणित चेतनप्रवाह शैली उनको औपन्यासिक पहिचान हो ।

अलिखित उपन्यासमा वीरगज्जको धरमपुर नजिक रहेको बिरहिनपुर बरेवा गाउँको वास्तविक परिस्थितिलाई उजागर गर्न खोजिएको छ। प्रयोगवादी उपन्यास भएकाले यसमा नायक, नायिका र कथानकको शृड्खला देखिंदैन। स्वैरकल्पनामा आधारित भएर उपन्यासले गति लिएको छ। लेखक स्वयम्ले 'त्यो गाउँलाई जहाँ बाँच्नुको अर्थ अस्पष्ट छ’ भन्ने विचार पोखेका छन्। यसले बिरहिनपुरको वास्तविकतालाई उजागर गरेको छ। उक्त गाउँ नेपालको नापी नक्सामा अलिखित हुनु र त्यस गाउँका हरेक गतिविधिहरू पनि अलिखित रूपमा नै देखिनु यसको प्रयोगात्मक पद्धति हो। सरकारले उक्त गाउंको सभ्यताको उत्वननका लागि पुरातत्त्व सम्बन्धी जानकारी प्राप्त गर्ने उद्देश्यले एक वर्षको योजनासहित पठाएको ११ सदस्यीय टोलीको कथालाई प्रस्तुत गर्नु नै उपन्यासको मुख्य अभिष्ट हो ।

अलिखित उपन्यासमा १४ वटा खण्ड र २४६ पृष्ठ रहेका छन्। आकारप्रकारका दृष्टिले यसलाई मध्यम आयामको उपन्यास मानिन्छ। यसमा कथावस्तु र पात्रहरू छैनन् । यसमा वीरगज्जको धरमपुर नजिक रहेको बिरहिनपुर बरेवा गाउँको सांस्कृतिक उत्वनन र त्यसका लागि काठमाण्डौबाट आएका ११ सदस्यीय टोली नै मुख्य 
पात्रका रूपमा रहेका छन्। 99 सदस्यीय टोलीको नाम र मंसिरदेखि कार्तिकसम्म पर्ने महिनालाई प्रत्येक टेली सदस्य र एउटा महिनालाई आधार मानेर उपन्यासको कथावस्तु बुनिएको छ। टोली सदस्य बस्ने घरको पारिवारिक वातावरण र गतिविधि उपन्यासको विषयवस्तु बनेको छ। उपन्यासमा परम्पराभन्दा भिन्न किसिमको औपन्यासिक मान्यता उजागर भएको छ। मिथकीय चिन्तन, स्वैरकल्पनात्मक पृष्ठभूमि, आज्चलिकताको प्रस्तुति र प्रयोगवादी अवधारणा यसका महत्वपूर्ण औपन्यासिक नवीन मान्यता र चिन्तनका रूपमा आएको देखिन्छ।

\section{समस्याकथन}

अनुसन्धानका लागि आवश्यकताअनुसार छनोट गरिएको विषय अनुसन्धेय विषय हो। अनुसन्धेय विषय नै लेखको शीर्षक पनि हो। अनुसन्धेय विषयलाई के कसरी प्रस्तुत गर्ने र लेखलाई सही गन्तव्यमा कसरी पुच्याउने भन्ने कुराको मार्गनिर्देशन समस्या हो। समस्यालाई शीर्षकको विषयवस्तु सम्भनु पर्दछ, (बन्धु, २०६५ :१७)। शीर्षकमा केन्द्रित रहेका प्रश्नहरू र ती प्रश्नहरूको सम्भावित उत्तरलाई नै समस्याकथन मानिन्छ, (भण्डारी, २०७४ : ९१)। 'नवीन औपन्यासिक मान्यता र चिन्तनका दृष्टिमा अलिखित उपन्यास' शीर्षकको अनुसन्धानमूलक लेखको समस्याकथनलाई निम्नअनुसार उल्लेख गरिन्छ :

क) अलिखित उपन्यासमा मिथकीय प्रयोग के कसरी गरिएको छ ?

ख) स्वैरकल्पनाका आधारमा अलिखित कस्तो उपन्यास हो ?

ग) अलिखित उपन्यासमा आज्चलिकताको प्रस्तुति कसरी गरिएको छ ?

घ) अलिखित उपन्यासमा पाइने प्रयोगवादी चिन्तन के कस्तो रहेको छ ?

\section{उद्देश्य}

कार्ययोजनाको महत्त्वपूर्ण उपलब्धि उद्देश्य हो। विना उद्देश्य कुनै पनि कार्य असम्भव देखिन्छ। लेखनका लागि उद्देश्यको किटान अनिवार्य सर्त हो। समस्या कथनमा देखाइएको बुँदाहरूको समाधान र निराकरण गर्ने काम नै उद्देश्य निर्धारण हो। समस्यामा उठान गरिएका बुँदाहरूलाई नै आधार मानेर लेख रचनालाई निश्चित गन्तव्य वा फलप्राप्तिमा पुच्याउनु यसको महत्त्वपूर्ण उपलब्धि हो । समस्या कथनमा अभिव्यक्त गरिएका प्रश्नहरूको उत्तर खोज्दै जाँदा लेखले मूर्त स्वरूपलाई आत्मसात गरेको पाइन्छ। 'नवीन औपन्यासिक मान्यता र चिन्तनका दृष्टिमा अलिखित उपन्यास' शीर्षकको अनुसन्धानमूलक लेखका उद्देश्यलाई निम्नअनुसार उल्लेख गरिन्छ :

क) अलिखित उपन्यासमा मिथकीय प्रयोगलाई स्पष्ट पार्नु,

ख) स्वैरकल्पनाका आधारमा अलिखित उपन्यासलाई चिनाउनु,

ग) अलिखित उपन्यासमा आज्चलिकताको प्रस्तुति देखाउनु,

घ) अलिखित उपन्यासमा पाइने प्रयोगवादी चिन्तनमाथि प्रकाश पार्नु ।

\section{शोधविधि तथा सामग्री}

अनुसन्धान गहन र महत्तवपूर्ण विषय हो। निरन्तरको अभ्यासबाट अनुसन्धानले सही गतिलाई आत्मसात गर्न सक्छ । अनुसन्धेय विषयलाई निश्चित गन्तव्यमा पुच्याउनका लागि अनुसन्धानसँग सम्बन्धित विभिन्न विधिहरूलाई उपयोग गरिन्छ। अनुसन्धानसँग सम्बन्धित प्रक्रिया नै अनुसन्धान विधि र पद्धति हो। 'नवीन औपन्यासिक मान्यता र चिन्तनका दृष्टिमा अलिखित उपन्यास' शीर्षकको अनुसन्धानका क्रममा पुस्तकालयीय विधिलाई नै मुख्य रूपमा आत्मसात गरिएको छ। यसमा द्वितीयक स्रोतका सामग्रीहरूलाई मुख्य रूपमा उपयोग गरिएको छ। वर्णनात्मक र 
विश्लेषणात्मक लेखन पद्धति यसको शैलीगत पक्ष हो। यस शीर्षकसँग सम्बन्धित महत्त्वपूर्ण पक्षलाई समेत पूर्वकार्यका रूपमा राखेर अनुसन्धानलाई वस्तुनिष्ठ बनाउने महत्त्वपूर्ण योजना यसमा गरिएको छ। सङ्कलित सामग्रीहरूको अध्ययन, विश्लेषण, खण्डन, मण्डन र सत्यापनलाई समेत प्रभावकारी ढड्गले गरिएको छ। अनुसन्धानमा उपयुक्त हुने विधिहरूलाई एकरूपताका साथ यहाँ प्रयोग गरेर लेखलाई अनुसन्धानमूलक बनाउने विशिष्ट प्रयत्न गरिएको छ।

\section{पूर्वकार्यको समीक्षा}

अनुसन्धान ज्ञानको खोजी गर्ने महत्त्वपूर्ण साधन र उपयुक्त माध्यम पनि हो। अनुसन्धाताले अनुसन्धान गर्ने अनुसन्धेय विषयका बारेमा पहिले भएका अनुसन्धान कार्यको लेखाजोखा र अध्ययन गर्ने विशिष्ट काम पूर्वकार्यको समीक्षा हो। पूर्वकार्यको समीक्षाले अनुसन्धानकार्यलाई निश्चित गन्तव्य र सही मार्गतर्फ डोचाउने गई। समस्या र उद्देश्यलाई सही निष्कर्षमा पुच्याई अनुन्धानलाई फलदायी बनाउन यसको भूमिका विशिष्ट मानिन्छ। 'नवीन औपन्यासिक मान्यता र चिन्तनका दृष्टिमा अलिखित उपन्यास' शीर्षकसँग सम्बन्धित रहेर पूर्वकार्यहरूको विवरणहरूलाई समीक्षा गर्नु सान्दर्भिक देखिन्छ। यसले पूर्वकार्यहरूको अध्ययनलाई पनि विशिष्ट आधार बनाएर मौलिकता दिने महत्त्वपूर्ण कार्य गरेको छ। यससँग सम्बन्धित अभिव्यक्त भएका पूर्ववर्ति विद्वान् समालोकहरूका विचार, धारणा र मान्यतालाई यहाँ समेट्ने प्रयास गरिएको छ।

सर्वप्रथम नेपाली साहित्यका मर्मज्ञ डा.दयाराम श्रेष्ठ र मोहनराज शर्मा (२०४९: पृ.११६) को नेपाली साहित्यको संक्षिप्त इतिहासमा ध्रुवचन्द्र गौतमको अलिखित उपन्यासलाई आधुनिक नेपाली उपन्यासको प्रयोगवादी धाराको औपन्यासिक कृतिका रूपमा उल्लेख गरेका छन्। उपन्यासले नयाँ जीवन नयाँ स्वरूप र नयाँ चिन्तन प्रकट गरेका आधारमा उपन्यासको औपन्यासिक महत्त्वको उजागर भएको बुकिन्छ।

नेपाली साहित्यका बहुमुखी प्रतिभाका धनी व्यक्तित्व माधवप्रसाद पोखरेल (२०४० : पृ. ४०) को पूर्वाज्चल समालोचनामा अलिखित उपन्यासको रचना शिल्प विशिष्ट प्रकृतिको रहेको र यसले नेपाली उपन्यास साहित्यमा नयाँपनलाई आत्मसात गरेको कुरा उल्लेख गरेका छन् । यसबाट उपन्यासले नयाँ स्वरूप ग्रहण गरेको बुकिन्छ।

नेपाली समालोचना जगत्का मूर्धन्य व्यक्तित्व हृदयचन्द्रसिंह प्रधान (२०४२: पृ. ४०७) को नेपाली उपन्यास र उपन्यासकार नामक समालोचनामा अलिखित उपन्यासलाई गौतमको सबैभन्दा उत्कृष्ट, भय, सन्त्रास, अन्योल सिर्जना गर्ने काल्पनिक उपन्यासका रूपमा चित्रण गरेका छन् । यसबाट अलिखित उपन्यासमा अभिव्यक्त आन्चलिक चिन्तनलाई अभिव्यक्त गरेको बुभिन्छ।

नेपाली साहित्यका मूर्धन्य समालोचक व्यक्तित्व गुणाकर भुसाल (२०४२ : पृ.३०४) को आधुनिक नेपाली आख्यान नामक कृतिमा अलिखित उपन्यासमा गरिब मानव समुदायको मूल्यहीन श्रम र पशुत्वरूपी जीवन लिएर बाँचेको प्रसड्ग उल्लेख गरेका छन् । यसबाट अलिखित उपन्यासमा दु:खी गरिबहरूको निराशा र पीडा अभिव्यक्त भएको पाइन्छ।

नेपाली साहित्यका समालोचक कृष्णहरि बराल र नेत्र एटम (२०४५ :पृ. २०) को उपन्यासको विश्लेषण कृतिमा अलिखित उपन्यासलाई प्रयोगवादी धाराको नयाँ उपलब्धिका रूपमा उल्लेख गरेका छन् । यसबाट अलिखित उपन्यासको विशिष्ट पक्षको उजागर भएको बुभिन्छ।

नेपाली साहित्यका समालोचक कृष्णहरि बराल र नेत्र एटम (२०४६६ :पृ. २७३) को उपन्यास सिद्धान्त र नेपाली उपन्यास नामक समालोचनात्मक कृतिमा अलिखित उपन्यासमा नियम कानुनमा उल्लेख नगरिएको, 
भ्रष्टाचार, हत्याको रेकर्ड नभएको, नेपालको नक्सामा समेत हराएको बिरहिनपुर बरेवा गाउँ अलिखित रहेको विचार अभिव्यक्त गरेका छन् । यसबाट अलिखित उपन्यासको शीर्षकको पुष्टि भएको बुभिन्छ।

नेपाली समालोचनाका क्षेत्रमा सुपरिचित नाम कृष्णप्रसाद आचार्य र कृष्णबहादुर बस्नेत (२०६३ : पृ. २प६६) को आधुनिक नेपाली उपन्यास र कथा कृतिमा अलिखित उपन्यासले भय आतङ्क सन्त्रास र शून्यवादी विचारलाई आत्मसात गरेको कुरा उल्लेख गरेका छन्। यसबाट अलिखित उपन्यासको मुख्य सारतत्त्व अभिव्यक्त भएको बुभिन्छ ।

नेपाली समालोचनाका फाँटमा उदीयमान समालोचक वासुदेव गौतम र अन्य (२०६९ : पृ. २६१) को नेपाली कथा र उपन्यास : सिद्धान्त र समीक्षा नामक पुस्तकमा आन्चलिकताका दृष्टिले अलिखित उपन्यासमा तराईको समाजको सजीव चित्रण गरेर उपन्यासलाई जीवन्तता प्रदान गरेको उल्लेख गरेका छन् । यसबाट अलिखित उपन्यासमा अभिव्यक्त तराईबासीको जनजीवनलाई स्पष्ट रूपमा उल्लेख गरेको बुभिन्छ।

नेपाली समालोचना जगत्मा मूर्धन्य समालोचकका रूपमा सुपरिचित समालोचक भोजराज ढुंगेल र दुर्गा दाहाल (२०६९ : पृ.३१६) को नेपाली कथा र उपन्यास नामक कृतिमा ध्रुवचन्द्र गौतमको अलिखित उपन्यास आज्चलिक उपन्यासको राम्रो नमुना हो। यसमा तराईको परिवेश, समाज, सभ्यता र संस्कारलाई समेत चित्रण गरेको विचार अभिव्यक्त गरेका छन् ।

नेपाली साहित्यमा कलम चलाएका समालोचक डा.घनश्याम दाहाल (२०७६ : पृ.१५०) को प्रमुख नेपाली उपन्यास र उपन्यासकार नामक कृतिमा अलिखित उपन्यास बिरहिनपुर बरेवाको महत्त्वपूर्ण दस्तावेज र नवीन प्रयोगको महत्त्वपूर्ण उपलब्धिका रूपमा उल्लेख गरेका छन् । यसबाट अलिखित उपन्यासको मूल मर्म खुलस्त भएको बुभिन्छ।

माथि उल्लेख गरिएका विद्वान्हरूका अलिखित उपन्यास सम्बन्धी विचारहरू महत्त्वपूर्ण र सारगर्भित देखिन्छन् । यस विषयमा लेखिएका सम्बन्धित पक्षका सामग्रीहरूको अपूर्णता नै देखिन्छ। त्यसैले यस अनुसन्धानमा अलिखित उपन्यासका सन्दर्भमा आएका महत्तवपूर्ण सबल र नवीन चिन्तन पक्षलाई सूक्ष्म रूपमा विश्लेषण गर्ने महत्त्वपूर्ण प्रयास गरिएको छ। यसले अलिखित उपन्यासका बारेमा खोज्न र पढ्न चाहने प्राजिक एवं बौद्धिक पाठकहरू पक्कै पनि लाभान्वित बन्नेछन् ।

\section{परिणाम तथा छलफल}

नेपाली आधुनिक उपन्यास जगत्को प्रयोगवादी धाराको उल्लेख्य उपन्यास अलिखित हो। यसमा तराई भूभागको जनजीवनको वास्तविक यथार्थलाई उल्लेख गरिएको छ। सरकारको आँखाले दृष्टि पुच्याउन नसकेको पिछडिएको गाउँको सांस्कृतिक उत्थान गरेर वास्तविक दस्तावेजलाई बाह्यप्रकटीकरण गर्ने महत्त्वपूर्ण कार्य यसमा गरिएको छ (बराल, २०५६ : २६०)। परम्परागत उपन्यासभन्दा भिन्न प्रस्तुति यसको महत्त्वपूर्ण उपलब्धि मानिन्छ। उपन्यासको कथावस्तु विशृड्खलित छ भने भ्रमण दलका ११ सदस्यकानाम नै पात्रका रूपमा आएका छन्। नेपाली उपन्यास जगत्मा नै नौलो शिल्प विधानलाई यसले आत्मसात गरेको छ ( पोखरेल, २०५०: ३६)। उपन्यासमा मिथकीय प्रयोग, स्वैरकल्पना, आन्चलिकता र प्रयोगवादी चिन्तनले अलिखित उपन्यासको औपन्यासिक मान्यता र विशिष्टतालाई सबल रूपमा आत्मसात गरेको छ। अन्य उपन्यासका तुलनामा यसले ल्याएको औचित्य, सार्थकता र नयाँ प्रयोगको आधार पनि यसले विशिष्ट रूपमा नै तयार गरेको देखिन्छ। यी विविध पक्ष नै उपन्यासले आत्मसात गरेको मर्म अवधारणा र चिन्तनको सूक्ष्म गहिराइ पनि हो। यसमा मिथकीय मान्यता, स्वैरकल्पनात्मक 
पृष्ठभूमि, आज्चलिकताको प्रस्तुति र प्रयोगवादी चिन्तनलाई सबल र सूक्ष्म रूपमा विश्लेषण गर्ने महत्वपूर्ण काम गरिएको छ।

\section{मिथकीय मान्यता}

अलिखित उपन्यास मिथकीय मान्यताका दृष्टिले उत्कृष्ट उपन्यास हो । मिथक पुराण इतिहास लोककथा किंवदन्ती आदिबाट लिइएको मानव संस्कृतिसँग सम्बन्धित विषय नै मिथक हुन् । मिथकमा मानवीय संस्कृतिको अमूल्य भण्डार पाइन्छ (बराल, २०६६ : २५३)। यसमा आदीम मानवले गरेका आनन्दानुभूति, भयानुभूति र रहस्यानुभूतिलाई काल्पनिक रूपमा उतारिएको हुन्छ। मिथकमा ईश्वरलाई मानवीकृत गरेर व्याख्या र पुनव्व्याख्या गरिन्छ। आदिम मानवहरूले गरेको व्यवहारहरूलाई उल्लेख गर्ने लोककथा, दन्त्यकथा र पौराणिक कथाका माध्यमबाट लिएर स्रष्टाले आफ्ना कृतिमा प्रस्तुत गरेका छन्। अलिखित मिथकहरूको सङ्कलन र पुनर्व्याख्या गरिएको महत्त्वपूर्ण उपन्यासका रूपमा रहेको छ।

अलिखित उपन्यासमा विरहिणीले बिरहिनपुर गाउँ नै सखाप होस् भन्ने श्राप दिएर मरेको किंवदन्ती पुस्तागत रूपमा चलेर आएको उल्लेख गरेको देखिन्छ। दुर्योधनको मृत्यु भएको द्वैपायन दह दोरहन्तल पोखरीका नामले प्रसिद्ध भएको किंवदन्ती जोडिएको पाइन्छ। यी दुवै मिथकहरूको सम्बन्ध र पुनर्व्याख्याले अलिखित उपन्यासलाई मिथकीय उपन्यासका रूपमा चिनाएको छ (भुसाल, २०४९, पृ. ३०४)। उपन्यासमा बिरहिनपुर बरेवा गाउँ आफैं मिथकीय बनेको छ। महाभारतकालीन दुर्योधन युद्धबाट भागेर पोखरीभित्र लुकेको र त्यहाँ धैरै धनसम्पत्ति राखेको विचार मिथकका रूपमा उल्लेख भएको छ। हनुमानले लङ्का डढाएर फिर्दा पुच्छर चाहिँ समुद्रमा चोपलेका कारण नदीबाट विहानीपख धुवाँको जस्तो वाफ आएको कुरालाई मिथकीय रूपमा प्रस्तुत छ। उपन्यासमा मान्छेलाई ढुंगा बनाएको, मान्छेले बोटमा फलेको चामल खाएकाले धान फल्न थालेको, साँक छरेपछि, बिहान फल्ने धानको मिथक बनाएर उपन्यासमा प्रभावकारी रुपमा प्रयोग गरिएको छ। उपन्यासको घटनाक्रमले उल्लेख गरेका बिरहिनपुरमा भएका सम्पूर्ण मान्छेहरू नै मिथक जस्ता देखिन्छन्। उपन्यासमा विभिन्न परिस्थितिका माध्यमबाट पुरा कथालाई पुनव्व्याख्या गरेर मिथकीय प्रयोगलाई सफल र उत्कृष्ट बनाएर प्रयोग गरेकाले अलिखित उपन्यास मिथकीय मान्यताका दृष्टिले सबल र सार्थक रहेको छ।

\section{स्वैरकल्पना}

अलिखित उपन्यास स्वैरकल्पनात्मक मान्यता र चिन्तनका आधारमा उत्कृष्ट उपन्यासका रूपमा उदाएको छ। उपन्यासमा प्रयुक्त घटना र परिस्थितिहरू स्वैरकल्पनामा आधारित देखिन्छन्। स्वैरकल्पना एउटा मानसिक कल्पना हो। हुनै नसक्ने अयथार्थ विषय र भएजस्ता लाग्ने अन्यौल संशय र दोधारपूर्ण अभिव्यक्ति आउने विषयको स्रोत स्वैरकल्पना हो (गौतम, २०६९ : २६२)। स्वैरकल्पना अवास्तविक र उडन्ते कल्पना हो। कल्पनाको आफ़ै संसारमा रमाउन चाहनु, सामान्य जीवनलाई समेत असामान्य बनाउनु, तर्कलाई पनि कुतर्कका रूपमा प्रस्तुत गर्नु, पाठक र स्रोतालाई केवल अलमल्याउने विचार राख्नु स्वैरकल्पनामूलक साधनस्रोतका मुख्य आधार हुन् । अलिखित उपन्यासमा स्वैरकल्पनालाई जटिल रूपमा प्रयोग गरिएको पाइन्छ। यथार्थलाई भ्रममा पारेर काल्पनिक संसारमा डुबुल्की मार्ने विषयलाई उपन्यासमा कथानकका रूपमा उपयोग गरिएको छ। स्वैरकल्पनाको प्रयोग भएका कारणले नै अलिखित उपन्यास बौद्धिक र जटिल हुन पुगेको छ।

देशको नक्सामा सबै समेटिए पनि बिरहिनपुर गाउँ चाहिँ नसमेटिनु हराएको देखिनु स्वैरकल्पना हो। द्वैपायन दहलाई दुर्योधनको मृत्युपछिको घटनाले दोरहन्तल पोखरीका रूपमा रूपान्तरण गर्नु र त्यो पोखरीसंग 
मान्छे डराउनु र त्यसले मान्छे निल्छ भन्नु स्वैरकल्पना हो (बराल, २प६ :२६२)। बिरहिनपुर हराएपछि पनि उक्त पोखरी गहिरो हुँदै जानु, चकिलो बन्दै जानु र विस्तृत आकारप्रकारको फैलावट ग्रहण गर्नु पनि स्वैरकल्पना हो। सांस्कृतिक उत्वननपछि 99 सदस्यीय टोली काठमाण्डौ प्रस्थान गर्नका लागि बिदाइका बखतमा दोरहन्तल पोखरीले लखेटेको र घेराबन्दीमा पारेका कारण डर र त्रासले अनुहार नै बिग्रिएको परिकल्पना गर्नु स्वैरकल्पना हो । उपन्यासमा स्वैरकल्पनालाई महत्त्वपूर्ण रूपमा आत्मसात गरेर औपन्यासिक मान्यता र चिन्तनलाई उत्कृष्ट बनाउने महत्त्पूर्ण प्रयास भएको पाइन्छ (प्रधान, २०४२ : ४०६)। उपन्यासमा काल्पनिक विषय, घटना र अयथार्थलाई स्वैरकल्पनाको मुख्य पृष्ठभूमि बनाएर सबल र सूक्ष्म रूपमा चित्रण गर्नु यसको स्वैरकल्पनात्मक मान्यता र पहिचान हो ।

\section{आक्चलिकता}

अलिखित उपन्यासमा तराइको जनजीवनको आज्चलिकताको प्रस्तुति सबल र सफल देखिन्छ। शंकर कोइरालाको खैरेनीघाट उपन्यासबाट नेपाली उपन्यास साहित्यमा आज्चलिक उपन्यास लेखन परम्पराको थालनी भई त्यसलाई समृद्ध, विकसित र उन्नत बनाउने सन्दर्भमा अलिखित उपन्यासको महत्त्वपूर्ण भूमिका देखिन्छ (ढुंगेल, २०६९:३१७) । कुनै ठाउँ वा क्षेत्र विशेषका जाति विशेषका कुनै ठोस विषयमा केन्द्रित रहेर त्यसैलाई उजागर गर्ने उद्देश्य राखेर लेखिएका उपन्यास आन्चलिक हुन् । यसमा स्थानीय परिवेशको प्रभाव महत्त्वपूर्ण रूपमा उजागर गरिएको छ। सहरिया क्षेत्रको भन्दा दुर्गम पिछडिएका क्षेत्र र व्यक्तिलाई मुख्य विषय बनाएर आज्चलिक उपन्यास लेखिन्छन् । यसमा तराई भूभाग वीरगज्जको धरमपुर नजिकको बिरहिनपुर बरेवा गाउँको मात्र चित्र फोटोग्राफरले खिचेको फोटोजस्तै गरी उतार्ने प्रयास गरिएको छ। यसमा त्यो गाउँका अशिक्षित परिवारहरूका विषयमा चित्रण गरिएको छ। त्यस गाउँका सोका सिधा जनताहरू जिम्दारको अन्यायको चपेटामा परेको दु:खद अवस्थालाई देखाइएको छ। यहाँ जिम्दारको हुकुमवादी सामन्ती संस्कारको उजागर गरिएको छ। गाउँका दु:खी र गरिबीको रेखामुनि रहेका महिलाहरूलाई कतै एक खिली बिंडीको प्रलोभन र कतै पैसाको प्रलोभनमा पारेर यौन अपहरण गरिएको परिस्थिति चित्रण छ। गाउँमा हुने गरेको कोर्रा हान्ने प्रचलन, जात काड्ने प्रचलन र विवाह हुन नसकेका महिलाहरूलाई बोक्सी भएर विवाह नभएको भन्ने संस्कारगत मान्यतालाई पनि उपन्यासमा देखाइएको छ। अशिक्षा र पछौटेपनका कारणले अनि राज्यको समेत त्यो दूरदराजको गाउँमा आँखा नपरेको र पार्न नचाहेका कारणले पनि गाउँ कारुणिक बनेको छ। त्यस ठाउँमा भोजपुरी लोक गीतको सांस्कृतिक भलक र प्रस्तुतिलाई समेत उपन्यासकारले उजागर गरेका छन् (गौतम, २६९ :२६१)। भोजपुरी समाजको सभ्यता, संस्कृति र आर्थिक अवस्था, राजनीतिक परिरदृश्यलाई समेत यहाँ उजागर गरिएको छ। उपन्यासमा मुख्य रूपमा तराई भूभाग वीरगज्ज एरियाको एउटा गाउँको सांस्कृतिक उत्बनन र अनुसन्धानमा मात्र केन्द्रित रहेर त्यस ठाउँका बारेमा देखिएका सम्पूर्ण कुराहरूको दस्तावेजीकरण गरिएको छ। उपन्यासमा तराई भूभागको जनजीवनको वास्तविक पक्षको सूक्ष्म र सबल रूपमा चित्रण गरेकाले अलिखित उपन्यासको आज्चलिकताको प्रस्तुति विशिष्ट र उल्लेखनीय बन्न पुगेको छ।

\section{प्रयोगशीलता}

अलिखित उपन्यास प्रयोगवादी अवधारणाको बहुमूल्य रचना हो । अलिखितमा परम्परागत औपन्यासिक मान्यताभन्दा भिन्न किसिमका नवीन मान्यतालाई आत्मसात गरिएको छ। यसमा नायक नायिकाको व्यवस्था रहेको पाइँदैन। कथानक भित्रको आदि, मध्य र अन्त्यको क्रम सहज र स्वाभाविक नभएर विशृड्खलित र खण्डित छ। विषयवस्तु पूर्ण रूपमा स्वैरकल्पनामा आधारित छ (बराल, २०५६ : २५२)। यसमा मंसिर महिनादेखि कार्तिक महिनासम्मको महिना गणना सँगसँगै सांस्कृतिक उत्बनन टोलीका सदस्यलाई पात्रका रूपमा एकै साथ वर्णन गरिएको छ। 
यसको कथावस्तु भनेकै 99 सदस्यीय टोलीका पात्र र उनीहरू बसेको घर र त्यहाँ भए गरेका कार्यहरू हुन्। नेपालको नक्सामा बिरहिनपुर बरेवा गाउँ हराएको भेटिनु त्यस गाउँमा भएका हरेक घटना र विशेषताहरूको कुनै लिखित दस्तावेज नै नभएकाले उपन्यासकारको लेखनी पनि त्यो गाउँको अलिखित विशेषता वर्णनमा नै केन्द्रित रहनु प्रयोगवादी लेखन हो (प्रधान, २१०५२ :४०९)। उपन्यासमा परम्परागत औपन्यासिक मान्यता र पहिचानभन्दा भिन्न भई नयाँ मान्यता र आधारको एउटा ठूलो दस्तावेज भएकाले पनि अलिखित उपन्यास प्रयोगवादी अवधारणालाई सबल रूपमा आत्मसात गरेर लेखिएको उत्कृष्ट उपन्यास बन्न पुगेको छ।

\section{चिन्तनीयता}

अलिखित गौतमको विशिष्ट दस्तावेजिक उपन्यास हो । यसमा परम्पराभन्दा भिन्न किसिमको औपन्यासिक चिन्तन मुखरित भएको छ। उपन्यासमा वीरगज्जको धरमपुर नजिकको बिरहिनपुर बरेवा गाउँको विचित्रको चित्रण गरिएको पाइन्छ। सरकारले सधैं उपेक्षा गरेको बिरहिनपुर बरेवा गाउँको वस्तुस्थितिलाई उत्वनन गरेर बाहिर निकाल्नु यस उपन्यासको मुख्य अभिष्ट रहेको देखिन्छ। राज्यले जिउँदा नागरिकको उचित सम्मान, उचित सेवा सुविधा र आवश्यकताको प्रत्याभूति दिन सकिरहेको छैन तर संस्कृतिको खोजी गर्ने नाममा मरेका मान्छेको कड्कालको खोजी गर्न जम्बो टोली पठाएर राष्ट्रको ढुकुटी रित्याउने खराब नियत राखेको भन्ने व्यड्ग्यात्मक अभिव्यक्ति पनि प्रकट भएको देखिन्छ।

प्रस्तुत उपन्यासमा सामन्ती संस्कारलाई देखाइएको छ। उपन्यासमा उल्लेख गरिएको गाउँ सामन्ती जिम्दारकै खटनपटन र आदेशमा चलेको देखिन्छ। गरिब, गुरुवा र असहायहरू उसबाट पीडित र प्रताडित छन् भने गरिबी नै गाउँको मुख्य कारक तत्त्व रहेको पाइन्छ (प्रधान, २०४२, पृ. ४०६)। अशिक्षाका कारणले नै गाउँलेहरूले वास्तविकतालाई बुक्न नसकी पुराना रुढी र किंवदन्तीहरूकै विश्वासमा परेर उनीहरूले आफ्नो जीवन चलाएका छन्। वीरगज्ज नजिकैको बिरहिनपुर गाउँको आज्चलिकताको वर्णन यसको महत्त्वपूर्ण प्राप्ति बनेको छ। तराइक्षेत्रको एउटा गाउँको वास्तविक तथ्य उजागर गर्नु उपन्यासको विशिष्ट चिन्तन देखिन्छ (बराल, २०४६ :२६९)। उपन्यासमा अनौठा प्राकृतिक दृश्यहरू रहेका छन् । हुँदै नभएको गाउँ भेटिन्छ तर यथार्थ गाउँ कल्पनामा मात्र सीमित छ। बिरहिनपुरको विकासका लागि राज्यले कुन चासो देखाएको पाइंदैन। राज्यले पुरिएको गाउँको उत्वनन गर्ने एक वर्षे योजना बनाए पनि गाउँका जिउँदा मान्छेका लागि कुनै योजना बनाएको पाइँदैन । त्यसकारणले पनि त्यो गाउँको अस्तित्व नामेट छ।

गाउँलेले आफ्नो गाउँको बारेमा खोजी गर्ने, त्यसका लागि दबाब दिने, कुनै ऋान्तिकारी आन्दोलन र विद्रोह गर्न सकेका छैनन् । उनीहरू भएर पनि क्रियाशील, गतिशील र अस्तित्ववान् छैनन् । गाउँलेहरू गतिशील हुन नसक्नुको मुख्य कारण गरिबी, अशिक्षा, पछ्छौटेपन र सामाजिक सामन्ती संस्कार रहेको पाइन्छ (भुसाल, २०५९, पृ. ३०४)। गाउँको प्रबुद्ध व्यक्ति इनरालाई दोरहन्तलमा मारेर फ्याँकिदिंदा, सुनरालाई षड्यन्त्र गरी जेल पठाउँदा, डाकाहरूको टोलीले गाउँलाई नै लुट्दा र तहसनहस बनाउँदा पनि गाउँलेहरूको प्रतिक्रिया केही पनि देखिंदैन । आफ्नो गाउँ र समाजका बारेमा गाउँलेहरू पनि बेखबर छन्। कहीं कसैलाई आफ़्नो गाउँको बारेमा खोजीनिन्दा छैन । उनीहरू आफ्नो गाउँ नै देशको मानचित्रबाट हराउँदा पनि किंवदन्तीलाई नै विश्वास गरेर बाँचेका छन्। आफ्नो अस्तित्व र पहिचानका लागि कुनै पानि गतिविधि गर्न सकेका छैनन् । उपन्यासका पात्र ऋषिराम भुर्तेलले बिरहिनपुरका बासिन्दाहरूमा विद्रोहको भावना, दबाबको भावना र आफ्नो गाउँ हराएकोमा चिन्ता नभएकाले नै गाउँ नै अलिखित बन्न पुगेको विचार राखेका छन्। बिरहिनपुर बरेवाको सामाजिक जीवन त्यहाँको रीतिरिवाज र वास्तविकतालाई उजागर गर्नु यस उपन्यासको मुख्य चिन्तन पक्ष हो । 


\section{निष्कर्ष}

उपन्यासकार ध्रुवचन्द्र गौतम प्रयोगवादी सबल र सफल उपन्यासकार हुन् । उनको अलिखित उपन्यास विशिष्ट चिन्तन र मान्यतालाई आत्मसात गरेर लेखिएको विशिष्ट उपन्यास हो। यसले नेपाली औपन्यासिक जगत्मा नयाँपनको सूत्रपात गरेको छ। खैरेनीघाटले ल्याएको आज्चलिकतामा यसले समृद्धि र उन्नयन गर्दे उल्लेख अवस्थामा पुग्याएको छ। वीरगऽ्जको धरमपुर गाउँ नजिकैको बिरहिनपुर बरेवा गाउँको विशिष्ट पहिचान र जनजीवनलाई उत्वनन गर्ने काम नै यसको मुख्य अभिष्ट र उपलब्धि बनेको छ। १४ वटा खण्ड र २४७ पृष्ठमा संरचित यसले नयाँ आयाम र चिन्तनलाई मुखरित गरेको छ। मंसिदेखि कार्तिक महिनासम्मको प्राकृतिक सौन्दर्यभित्र उत्वनन टोलीका सदस्य पात्रहरूको अन्तर्सम्बन्धलाई प्रभावकारी रूपमा प्रस्तुत गरेर उपन्यासलाई सर्वथा नौलोपन दिन प्रयत्न गरिएको छ।

उपन्यासले पाउने कथानक र त्यसले पनि प्राप्त गर्ने आदि, मध्य र अत्यको अवस्था यस उपन्यासमा पाइंदैन । उपन्यास पढ़दै जाँदा पाठकहरूले यसलाई अउपन्यासका रूपमा पनि हेर्ने आधार र तथ्य पाउन सक्छन् । बिरहिनपुरको वास्तविक जीवनको दस्तावेजलाई यसले वर्णनात्मक शैलीमा उतार्ने महत्त्वपूर्ण काम गरेको छ। त्यस गाउँको गरिबीले ल्याएको पछौटेपनलाई उजागर गरिएको छ। त्यहाँ हुने गरेका हत्या, आतङ्क, चोरीडकैती, यौन अपहरण र आगजनीजस्ता दुर्घटनालाई अत्यन्त सामान्यरूपमा चित्रण गरिएको छ। गाउँलेले दु:ख, कष्ट र निराशालाई सजिलैसँग पचाएको वास्तविक यथार्थपनि उपन्यासमा अभिव्यक्त भएको छ। राणाकालीन हुकुमी शासनको परिदृश्य पनि जिम्दारका माध्यमबाट सबल रूपमा बाह्य प्रकटीकरण गरिएको छ। एउटा सिड्गो गाउँको जनजीवनको फोटोग्राफिक चित्र उतार्नु यसको मुख्य प्राप्ति देखिन्छ ।

यस उपन्यासमा विरहिणीको श्रापका कारण सदाका लागि लोप भएर किंवदन्तीका रूपमा पुस्तौं पुस्ता फैलिंदै गएको बिरहिनपुरको कथा र व्यथा पोखिएको छ। महाभारतकालीन युद्धबाट भागेर पोखरीभित्र लुकेको र त्यहाँ अपार धनसम्पत्ति राखेको, दुर्योधनको मृत्युपछि, उसैको नाम बिगारेर नामाकरण गरिएको, डरत्रासले भरिएको दोरहन्तल पोखरीको किंवदन्तीको कथा पनि यसमा उल्लेख छ। मिथकीय चिन्तनले उपन्यासलाई औचित्यपूर्ण बनाएको छ। धार्मिक भावना र विचारबाट अभिप्रेरित विभिन्न कथाहरूलाई पुनव्व्याख्या गरेर यथार्थजस्तो बनाई यसमा प्रभावकारी रूपमा पस्कने प्रयत्न गरिएको छ। यसले उपन्यासको गरिमा र संरचनागत विशिष्टतालाई उजागर गरेको बुकिन्छ।

यसले नेपाली उपन्यास जगत्मा नयाँ कान्तिकारी औचित्यलाई आत्मसात गरेको छ। विषयवस्तु र पात्रको अभावमा उपन्यासको संरचना हुनु यसको नवीन प्रयोग हो। विभिन्न स्वैरकल्पनालाई वास्तविकतामा ढालेर औपन्यासीकरण गर्नु यसको प्रयोगवादी शैली र शिल्पको उत्कृष्ट उपलब्धि हो। एउटै मात्र क्षेत्रलाई मुख्य केन्द्रविन्दुमा राखेर त्यसका बहुमुखी पक्षको उद्घाटन गरेर बाह्यप्रकटीकरण गर्नु आधुनिक उपन्यासको नयाँ संरचनागत प्राप्ति हो। यसले ल्याएको आन्तरिक र बाह्य मिश्रित दृष्टिविन्दु र शीर्षकीकरणले ल्याएको नयाँ मान्यता पनि नयाँपनको द्योतक हो। औपन्यासिक चिन्तनभित्रको विशिष्टता, प्रयोगशीलता, आज्चलिकता र स्वैरकल्पना यस उपन्यासले ल्याएका औपन्यासिक मान्यता र विशिष्ट पहिचान हुन् । आधुनिक उपन्यास जगत्मा 
प्रवर्तन गरेको नौलो दस्तावेजीकरणले यसको गरिमालाई सबल, सफल र उच्च बनाउने महान् प्रयत्न नै यस उपन्यासको मूलभूत उपलब्धि, प्राप्ति र निष्कर्ष हो ।

\section{सन्दर्भसामग्री}

आचार्य, कृष्णप्रसाद र बस्नेत, कृष्ण बहादुर (२०६३). आधुनिक नेपाली उपन्यास र कथा. दीक्षन्त पुस्तक प्रकाशन ।

गौतम, वासुदेव र अन्य (२०६९). नेपाली कथा र उपन्यास : सिद्धान्त र समीक्षा. भुँडीपुराण प्रकाशन ।

ढुंगेल, भोजराज र दाहाल, दुर्गाप्रसाद (२०६९). नेपाली कथा र उपन्यास. एम. के. पब्लिसर्स ।

दाहाल, घनश्याम (२०७६). प्रमुख नेपाली उपन्यास र उपन्यासकार. काष्ठमण्डप प्रकाशन ।

पोखरेल, माधवप्रसाद (२०४०). अलिखित उपन्यासको रचना विधान. पूर्वाज्चल समालोचना, (सम्पा. नरेन्द्र चापागाइँ), पूर्वाज्चल साहित्य प्रतिष्ठान ।

प्रधान, कृष्णचन्द्रसिंह (२०४२). नेपाली उपन्यास र उसन्यासकार (ते.सं.). साभा प्रकाशन ।

बन्धु, चूडामणि (२०६४). अनुसन्धान तथा प्रतिवेदन लेखन. रत्न पुस्तक भण्डार ।

बराल, कृष्णहरि र एटम, नेत्र (२०५५ ). उपन्यासको विश्लेषण. नवीन प्रकाशन ।

बराल, कृष्णहरि र एटम, नेत्र (२०४६). उपन्यास सिद्धान्त र नेपाली उपन्यास. साका प्रकाशन ।

भण्डारी, पारसमणि (२०७४). अनुसन्धान विधि. विद्यार्थी पुस्तक भण्डार ।

भुसाल, गुणाकर (२०४९). आधुनिक नेपाली आख्यान, क्षितिज प्रकाशन.

राई, इन्द्रबहादुर (२०४०). नेपाली उपन्यासका आधारहरू. (दो.सं.). ललितपुर : साका प्रकाशन.

श्रेष्ठ, दयाराम र शर्मा, मोहनराज (२०४९). नेपाली साहित्यको संक्षिपत इतिहास (च.सं.). साभा प्रकाशन. सुवेदी, राजेन्द्र (२०४३). नेपाली उपन्यास परम्परा र प्रवृत्ति. भूमिका प्रकाशन । 